Arq. Bras. Med. Vet. Zootec., v.66, n.3, p.797-800, 2014

\title{
Cutaneous toxoplasmosis in an immunosuppressed dog
}

\author{
[Toxoplasmose cutânea em um cão imunosuprimido] \\ T.S. Oliveira ${ }^{1}$, A.P. Turchetti ${ }^{1}$, F.B.S. Barbosa ${ }^{2}$, A.L.F. Bicalho ${ }^{2}$, C.A.D. Alencar ${ }^{2}$, \\ T.A. Paixão ${ }^{3}$, R.L. Santos ${ }^{1} *$ \\ ${ }^{1}$ Escola de Veterinária - Universidade Federal de Minas Gerais - Belo Horizonte, MG \\ ${ }^{2}$ Clínica Veterinária São Francisco de Assis - Belo Horizonte, MG \\ ${ }^{3}$ Instituto de Ciências Biológicas - Universidade Federal de Minas Gerais - Belo Horizonte, MG
}

\begin{abstract}
A seven-year-old female spayed Schnauzer was presented with cutaneous ulcerated nodular lesions shortly after the beginning of an immunosuppressive treatment for immune-mediated hemolytic disease. Cytology was performed and a great number of neutrophils and banana-shaped organisms were observed. Biopsy showed a neutrophilic and histiocytic dermatitis and panniculitis with myriads of intralesional bradyzoites cysts and tachyzoites. PCR analysis was positive for Toxoplasma gondii and negative for Neospora caninum. Immunohistochemistry confirmed intralesional $T$. gondii antigens. This study reports a rare case of cutaneous toxoplasmosis in an immunosuppressed dog.
\end{abstract}

Keywords: dog, toxoplasmosis, cutaneous, immunosuppression

\section{RESUMO}

Uma cadela Schnauzer, castrada, de sete anos apresentou lesões cutâneas nodulares ulceradas pouco tempo após início de tratamento imunossupressor para doença hemolítica imunomediada. Foi realizado exame citológico, e um grande número de neutrófilos e estruturas em forma de banana foi observado. Biópsia mostrou dermatite e paniculite neutrofilica e histiocítica com miríades de taquizoítos e cistos de bradizoítos intralesionais. PCR foi positivo para Toxoplasma gondii e negativo para Neospora caninum. Imuno-histoquímica confirmou antígenos de T. gondii intralesionais. Este trabalho relata um caso raro de toxoplasmose cutânea em um cão imunossuprimido.

Palavras-chave: cão, toxoplasmose cutânea, imunossupressão

\section{INTRODUCTION}

Toxoplasmosis is a disease caused by Toxoplasma gondii, a coccidian protozoan that belongs to the Sarcocystidae family. While wild cats are definitive hosts, the domestic cat is the most important definitive host due to its proximity with humans, whereas other mammals and birds can become infected by ingesting cysts from uncooked meat or protozoan oocysts present in food contaminated with feces from infected cats. Vertical or transplacentary transmission can also occur. Once infected, immunocompetent intermediate hosts may

Recebido em 27 de maio de 2013

Aceito em 18 de dezembro de 2013

*Autor para correspondência (corresponding author)

E-mail: rsantos@vet.ufmg.br develop an efficient immune response, and the protozoan cysts become latent. However, under immunosuppressive conditions the host becomes more susceptible to $T$. gondii proliferation, which may be associated with the rupture of the cysts and development of clinical disease.

Clinical features of toxoplasmosis are usually lesions in the central nervous system, lungs, and eyes (Montoya and Liesenfeld, 2004). Uncommonly, cutaneous lesions can be observed in human patients, who can present erythema multiforme-like eruptions, nodular, maculopapular, papulopustular, lichenoid, or vegetative dermatitis (Mawhorter et al., 1992). 
Cats may rarely develop a single cutaneous nodule (Park et al., 2007) or multiple ulcerated and nonulcerated cutaneous nodules (Anfray et al., 2005). Two cases of cutaneous toxoplasmosis have been diagnosed in a study involving 100 cats with clinical toxoplasmosis (Dubey and Carpenter, 1993). There are only two previous reports of cutaneous lesions associated with toxoplasmosis in dogs. In the first report, the dog had multiple raised, alopecic, and ulcerated nodules with some nodules draining a purulent exudate (Webb et al., 2005). Other two cases have been recently reported (Hoffmann et al., 2012), describing a dog that developed a generalized pustular dermatitis with pruritus, and a second case with a single cutaneous raised nodule.

\section{CASE REPORT}

A seven-year-old female spayed white Schnauzer was presented with moderate anemia and was clinically diagnosed with an immune-mediated hemolytic disease (IMHA). In the past three years, the animal had had five other episodes of IMHA responsive to oral prednisone treatment. The initial dose was of $1 \mathrm{mg} / \mathrm{kg}$ every 24 hours, with gradual decrease. Treatment duration varied between two to eight weeks depending on clinical response. After the first episode, the animal received two blood transfusions due to severe anemia. In this last episode, treatment with prednisone was started. However, the animal failed to respond as expected. After one month, hematocrit continued to decrease and oral treatment was changed to prednisolone $(2 \mathrm{mg} / \mathrm{kg} / 48 \mathrm{~h})$, acetyl salicylic acid $(0.5 \mathrm{mg} / \mathrm{kg} / 24$ h) and azathioprine $(2 \mathrm{mg} / \mathrm{kg} / 48 \mathrm{~h})$. Seven days later, the animal was admitted due to deterioration in the clinical status and the development of cutaneous ulcerated nodular lesions with seropurulent secretion.

A complete blood exam from the admission day showed icteric serum, moderate nonregenerative anemia (hematocrit $26.2 \%$ ), a marked increase in alkaline phosphatase $(1,423 \mathrm{U} / \mathrm{L})$ and a mild increase in alanine aminotransferase (354 U/L) and gamma-glutamyl transferase (61 U/L). Total leukocytes, platelets, total protein, urea, creatinine, calcium, phosphorus, total cholesterol, and triglycerides were within normal ranges. Ultrasound imaging showed hepato and splenomegaly. Secretion from the cutaneous lesions was collected on the admission day and had no bacterial growth. Cytology of the secretion stained with May-Grunwald-Giemsa revealed a large number of neutrophils with some macrophages and many banana-shaped organisms with approximately 3 x $1.5 \mu \mathrm{m}$ (Fig. 1A).

A biopsy of a skin lesion was performed, the fragment consisted of $0.8 \mathrm{~cm}$ in diameter, white to brownish, soft to friable, solid nodular lesion. Tissue samples were fixed by immersion in $10 \%$ buffered formalin, and processed for paraffin embedding. Four $\mu \mathrm{m}$ sections were stained with hematoxylin and eosin (H\&E). There was a neutrophilic and histiocytic, multifocal to coalescing, severe inflammatory infiltrate extending from the superficial into the deep dermis and hypodermis, with several degenerated neutrophils (Fig. 1B and 1C). Numerous cysts ranging from 8 to $30 \mu \mathrm{m}$ containing multiple round $2 \mu \mathrm{m}$ bradyzoites and numerous free elongated 2 to $3 \mu \mathrm{m}$ tachyzoites were observed within the inflamed tissue (Fig. 1C). Multifocal to coalescing moderate necrosis was also observed. Other findings included multifocal moderate collagenolysis, ortokeratotic lamellar hyperketatosis, multifocal mild ectasia of apocrine glands, and accumulation of cytosolic brown granules within histiocytes (which were interpreted as hemosiderin). In one of the fragments there was a focally extensive area of ulceration, and in another section there was a focally extensive intense accumulation of fibrillar eosinophilic material (fibrin) in the epidermal surface. The morphologic diagnosis of neutrophilic and histiocytic dermatitis and panniculitis with myriads of intralesional bradyzoites cysts and tachyzoites in this case is consistent with $T$. gondii or Neospora caninum infection. In order to distinguish between the two pathogens, PCR was carried out. DNA extraction was performed using $100 \mu \mathrm{m}$ thick sections from paraffin-embedded tissue using the DNeasy Blood and Tissue Kit [Qiagen, Brazil], according to the manufacturer's instructions. PCR for detection of $N$. caninum genomic DNA was carried out as previously described (Silva et al., 2009), and resulted in the absence of amplification of the pNC-5 gene. A previously described nested PCR was used for amplification of T. gondii genomic DNA (Lin et al., 2000). A specific 131 base-pair product corresponding to a sequence of the $T$. gondii B1 gene was amplified. 
Positive and negative controls were included in all PCR reactions. To further confirm the diagnosis, immunohistochemistry (IHC) was performed. Four $\mu \mathrm{m}$ tissue sections were labeled by the peroxidase method [Dako North America Inc., USA]. A polyclonal T. gondii antibody was used as primary antibody, DAB served as chromogen, and Mayer's haematoxylin as counterstain. The immunohistochemistry protocol was performed at an accredited commercial diagnostic laboratory [TECSA, Brazil]. The cysts and free tachyzoites were immunostained confirming the diagnosis of cutaneous toxoplasmosis (Fig. 1D). Treatment with clindamycin $(30 \mathrm{mg} / \mathrm{kg} / 12 \mathrm{~h})$ was initiated, but the dog died one day after the beginning of this treatment.
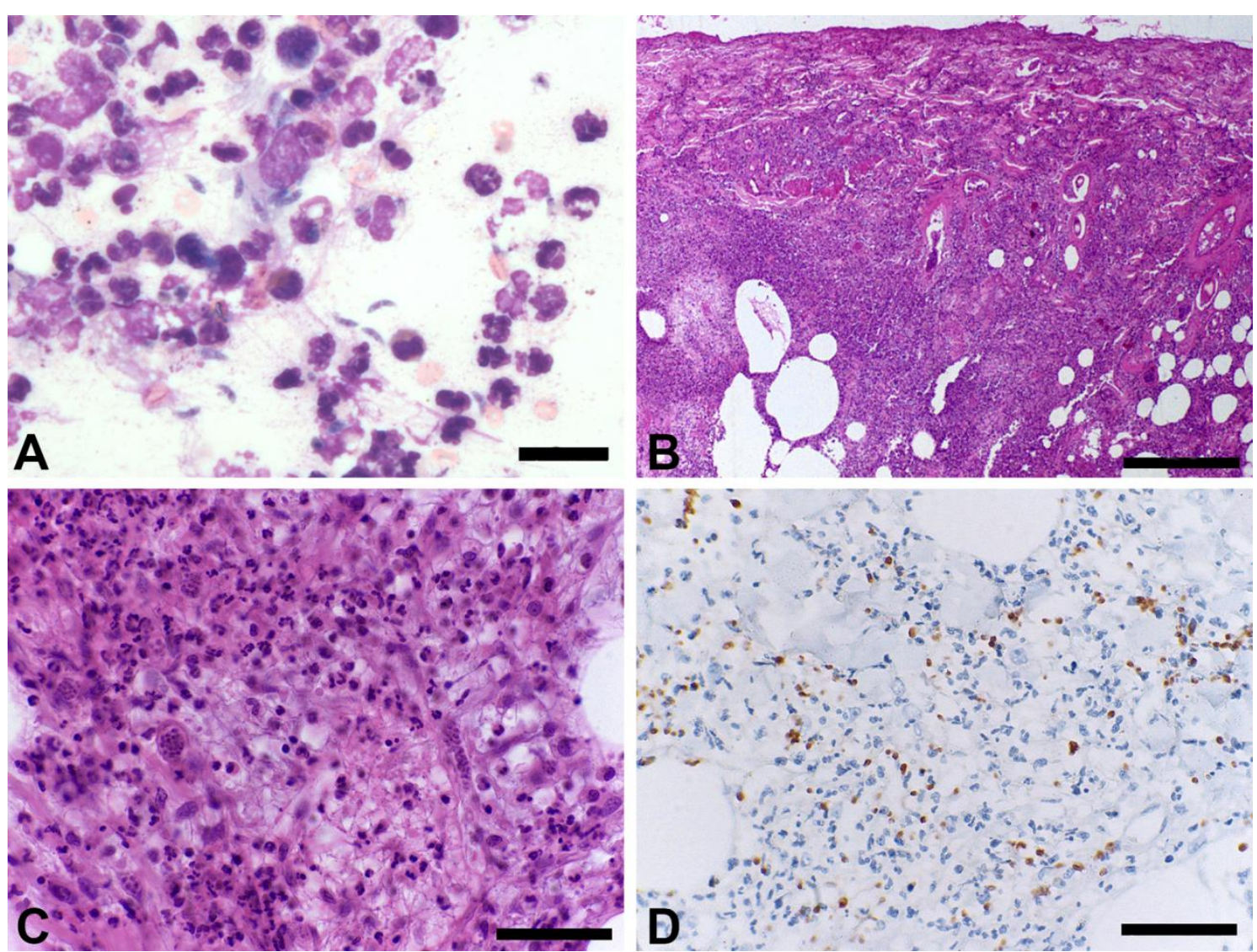

Figure 1. Immunosuppressed dog with cutaneous toxoplasmosis. (A) Cytology preparation of secretion draining from one of the cutaneous lesions, stained with May-Grunwald-Giemsa. Large number of neutrophils with some macrophages and many banana-shaped organisms with approximately $3 \times 1.5 \mu \mathrm{m}$. Bar $=20 \mu \mathrm{m}$. (B) Haired skin. Multifocal to coalescing intense inflammatory infiltrate in the dermis and hypodermis. H\&E, Bar $=500 \mu \mathrm{m}$. (C) Haired skin. The inflammatory infiltrate is composed predominantly of degenerated neutrophils and hystiocytes, with numerous free tachyzoites and cysts containing bradyzoites. H\&E, Bar $=50 \mu \mathrm{m}$. (D) Haired skin. Positive immunostaining of tachyzoites and bradyzoites. IHC - Avidin biotin peroxidase complex method, Mayer's haematoxylin counter stain, Bar = $50 \mu \mathrm{m}$.

\section{DISCUSSION}

Despite the treatment for IMHA and toxoplasmosis, the animal died one day after the diagnosis and beginning of the treatment with clindamycin, and the owner did not authorize a necropsy. Therefore, it was not possible to determine whether the lesions were a cutaneous manifestation from a case of disseminated toxoplasmosis or primary cutaneous form of the disease. Webb et al. (2005) reported a case of disseminated toxoplasmosis with cutaneous 
manifestation in a male giant Schnauzer, which was also immunosuppressed due to treatment with prednisone, azathioprine, and cyclosporine for immune-mediated hemolytic anemia. The other two cases of cutaneous toxoplasmosis in dogs were also related to immunosuppression (Hoffmann et al., 2012). Regardless of the host species, the vast majority of cases of symptomatic toxoplasmosis is associated with immunosuppression (Montoya and Liesenfeld, 2004; Park et al., 2007). Clindamycin is a drug indicated for the treatment of toxoplasmosis, but in this case the dog died despite treatment. Hoffmann et al. (2012) describes successful treatment of localized cutaneous toxoplasmosis using clindamycin, however it was not efficient for a dog with cutaneous disseminated toxoplasmosis. Although protozoal diseases may have cutaneous manifestations, with the exception of leishmaniasis, these are rarely seen in dogs (Ferrer et al., 1988). Possible etiologic agents of cutaneous protozoosis in dogs include Leishmania spp., Caryospora spp., and Sarcocystis canis, in addition to T. gondii and $N$. caninum (Webb et al., 2005). A curious case of dermatitis caused by a $T$. gondii-like organism in a dog has been described, but electron microscopy excluded cutaneous toxoplasmosis (Dubey et al., 2003). T. gondii does not produce any toxins, and therefore induces necrosis and tissue damage due to intracellular multiplication in host cells (Dubey and Lappin, 1998). Thus, the histopathological findings in this case are consistent with the $T$. gondii pathogenesis. Although rare, cutaneous toxoplasmosis should be included in the differential diagnosis of cutaneous lesions in dogs, especially those immunosuppressed.

\section{ACKNOWLEDGMENTS}

Work in RLS lab is supported by $\mathrm{CNPq}$ (Conselho Nacional de Desenvolvimento Científico e Tecnológico) and FAPEMIG (Fundação de Amparo a Pesquisa do Estado de Minas Gerais). Immunohistochemistry was performed at TECSA (Belo Horizonte, Brazil).

\section{REFERENCES}

ANFRAY, P.; BONETTI, C.; FABBRINI, F. et al. Feline cutaneous toxoplasmosis: a case report. Vet. Dermatol., v.16, p.131-136, 2005.

DUBEY, J.P.; CARPENTER, J.L. Histologically confirmed clinical toxoplasmosis in cats: 100 cases (1952-1990). J. Am. Vet. Med. Assoc., v.203, p.1556-1566, 1993.

DUBEY, J.P.; LAPPIN, M.R. Toxoplasmosis and neosporosis. In: GREENE, C.E. (Ed). Infectious Diseases of the Dog and Cat. Philadelphia: WB SAUNDERS, 1998. p.493509.

DUBEY, J.P.; PIMENTA, A.L.; ABBOUD, L.C.S. et al. Dermatitis in a dog associated with an unidentified Toxoplasma gondii-like parasite. Vet. Parasitol., v.116, p.51-59, 2003.

FERRER, L.; RABANAL, R.; FONDEVILA, D. et al. Skin lesions in canine leishmaniasis. $J$. Small. Anim. Pract., v.29, p.381-388, 1988.

HOFFMANN, A.R.; CADIEU, J.; KIUPEL, M. et al. Cutaneous toxoplasmosis in two dogs. J. Vet. Diagn. Invest., v.24, p.636-640, 2012.

LIN, M.H.; CHEN, T.C.; KUO, T.T. et al. Realtime PCR for quantitative detection of Toxoplasma gondii. J. Clin. Microbiol., v.38, p.4121-4125, 2000.

MAWHORTER, S.D.; EFFRON, D.; BLINKHORN, R.; SPAGNUOLO, P.J. Cutaneous manifestations of toxoplasmosis. Clin. Infect. Dis., v.14, p.10841088, 1992.

MONTOYA, J.G.; LIESENFELD, O. Toxoplasmosis. Lancet, v.12, p.1965-1976, 2004.

PARK, C.H.; IKADAI, H.; YOSHIDA, E. et al. Cutaneous toxoplasmosis in a female Japanese cat. Vet. Pathol., v.44, p.683-687, 2007.

SILVA, T.M.A.; OLIVEIRA, R.G.; MOL, J.P.S. et al. Etiologic diagnosis of bovine infectious abortion by PCR. Cienc. Rural, v.39, p.25632570, 2009.

WEBB, J.A.; KELLER, S.L.; SOUTHORN, E.P. et al. Cutaneous manifestations of disseminated toxoplasmosis in an immunosuppressed dog. $J$. Am. Anim. Hosp. Assoc., v.41, p.198-202, 2005. 